\title{
Die huwelik as identiteitsmerker in die Ou Testament
}

\author{
Pieter M Venter \\ Departement Ou-Testamentiese Wetenskap \\ Universiteit van Pretoria
}

\begin{abstract}
Marriage as identity marker in the Old Testament

The formularies used for consecrating marriages in the Nederduitsch Hervormde Church reflect this church's view on matrimony. As the biblical bases of the formularies are deficient, new ways of exploring biblical information on this subject should be followed. This article proposes that data on marriage in the Bible always be used in conjunction with other concepts to form theological constructs to outline who God is and who his people are. It is always intended to be an identity marker to the members of the church. In the three Genesis cycles of Genesis 11:10-25:11; 25:1235:29 and 36:1-50:26 heirship, marriage and land are used in an integrated construct to indicate the identity of the post-exilic community in Yehud. In the penitential prayers of Ezra 9:6-15 and Nehemia 9:5b-37 the concepts law, land and marriage are jointly used to depict the identity of the "real" Israel. The conclusion drawn from this investigation is that the Bible does not present models for marriage, but rather theological constructs to understand the relationship with the Lord in metaphorical terms and to reflect on the meaning of everyday life of that relationship including matrimony under ever changing social circumstances.
\end{abstract}

\section{INLEIDING}

'n Kerk formuleer in die formuliere wat hy gebruik sy teologiese siening van sake soos die doop, die nagmaal, of die huwelik. In die Diensboek van die Nederduitsch Hervormde Kerk van Afrika is daar drie formuliere opgeneem wat as wisselvorme vir die bevestiging van die huwelik gebruik kan word. ${ }^{1}$ Hierdie huweliksformuliere verteenwoordig die beskouing van die Hervormde

\footnotetext{
${ }^{1}$ Ek werk hier met die elektroniese weergawe van die Huweliksformuliere soos dit beskikbaar was op 18 Junie 2007 by http:Iwww.nhk.co.za/HOOF.htm/Diensboek/Formuliere vir die bevestiging van die huwelik (1), (2), en (3).
} 
Kerk oor die huwelik. Die formuliere pretendeer om gesaghebbende teologiese uitsprake ${ }^{2}$ oor die huwelik te maak.

Vanuit die vakgebied van die Ou-Testamentiese Wetenskap kan hierdie formuliere as verengend en selfs misplaas gesien word. Bepaalde gedeeltes uit die Bybel word eklekties gebruik om die huwelik te legitimeer as skeppingsordinansie (Gen 2-3), ${ }^{3}$ as onlosmaaklike band wat God gesmee het (Matt 19:3-9, vgl Deut 24:1-4) en as instelling wat gereël word volgens Kolossense 3:18-19. Die bepaalde Skrifgedeeltes waarna verwys word, word gelees as uitsprake oor die huwelik sonder om te kontroleer of dit wel in die bepaalde gedeeltes die fokuspunt daarvan vorm en of dit wel gaan oor die huwelik as instelling in daardie dele. Daar word geen aandag gegee aan die literêre tipe van die gedeeltes of die groter literêre struktuur van die bepaalde eenhede waarin die Bybeldele voorkom nie.

Hierdie opmerkings kan kortlik geïllustreer word aan die hand van uitsprake wat in die drie huweliksformuliere gemaak word. Die eerste formulier begin met die woorde: "Hoor dan nou uit die Heilige Skrif hoe 'n eerbare instelling van God die huwelik is en dat dit Hom behaag". Die bewysgrond is "dat God, ons Vader, nadat Hy die hemel en alles daarin en die aarde en alles daarop, geskep het, die mens as sy beeld gemaak het" (vgl vir "beeld" Gen 1:26). Dan volg 'n aanhaling van Genesis 1:28 oor die opdrag om vrugbaar te wees en die aarde te bewoon en te bewerk. Dit word gevolg deur die woorde van Genesis 2:18 oor die alleenheid van die mens en met weglating van Genesis 2:19-20 verder gevolg met 'n aanhaling van Genesis 2:21-24. In die tweede formulier word ook aangehaal uit Genesis 2:18 en soos in die eerste formulier klem gelê op Genesis 2:22 se woorde dat God die vrou na die mens gebring het. Hieruit word net soos in die derde formulier afgelei dat God self die huwelik ingestel het. Ook die derde formulier werk daarmee dat God die mens as twee verskillende geslagte gemaak het (dus die huwelik "geskep" het), die erkennnig van die mens dat die ander mens wat God na hom gebring het "nou eindelik been van my gebeente en vlees van my vlees" (Gen 2:23) is en dat God dus aan man en vrou wedersyds 'n paslike helper gegee het (vgl Gen 2:18). Uit die woorde van Genesis 2:24 dat man en vrou een sal wees, lei die derde formulier af dat dit "getuig dat die huwelik 'n allesinsluitende gemeenskap is tussen net een man en een vrou. Met die oog daarop het Jesus gesê dat wat God saamgevoeg het, die mens nie mag skei nie. Ook op

\footnotetext{
${ }^{2}$ Vgl die aanspraak dat die formuliere aanbied "wat die Heilige Skrif oor die huwelik leer" (vgl Formulier 3).

${ }^{3}$ Vgl die kensketsing van God as "die Here wat die hemel en die aarde gemaak het" in Formulier 1.
} 
ander plekke in die Bybel verneem ons die duidelike getuienis dat die huwelik 'n onverbreekbare en onophefbare verbintenis is vir die ganse duur van ons aardse lewe". Die monogame huwelik en die onontbindbaarheid daarvan word uit hierdie gedeeltes dus as skeppingsordinansie gesien.

Hierdie letterlike en selektiewe Skrifgebruik ignoreer die afsonderlike literêre konstruksies waarin die Bybel se inhoude gegiet is. Dit verontagsaam ook die narratiewe literêre tipe waarin die materiaal kommunikeer en fokus buite verband op dit wat as die oorsprong van die huwelik gesien word. Genesis 1:1-2:4a vorm 'n selfstandige skeppingsverhaal wat simmetries opgebou is rondom sewe "skeppinsgdae". Die orde in die wêreld en die hoogtepunt van die sewende dag (sabbat) is die opsigtelike kernpunte. Genesis 2:4b-3:24 is ' $n$ tweede skeppingsverhaal met heeltemal ' $n$ ander volgorde waarin God die wêreld geskep het. Hier vorm die aardbodem en die mens se vervreemding van die tuin die fokuspunte. Albei verhale is ook narratiewe literatuur wat God as skepper van alles wil bely. Dit wil verklaar waar die orde in die skepping vandaan kom en hoekom dit versteur is deur die mens se ongehoorsaamheid. Die onderskeie vertellings het ook opsigtelik twee agtergronde, Genesis 1 het 'n priesterlike konteks en Genesis 2-3 het 'n landbou raamwerk. Om selektief gegewens willekeurig uit albei hierdie vertellings te onttrek, buite verband te kombineer en daarvan skeppingsordinansies te maak, druis reëlreg in teen die aard daarvan. ${ }^{4}$

In die Bybel word ook nog op talle ander plekke na die huwelik verwys as die sosiale verskynsel van man en vrou wat met medewete en toestemming van die gemeenskap waarin hulle woon, in 'n seksuele verhouding met mekaar saamleef. Dit is egter opvallend dat verwysings na die "huwelik" as sosiale verskynsel altyd binne 'n groter gedagtekompleks gebruik word. So word, byvoorbeeld op talle plekke in Hosea, Jeremia, Klaagliedere van Jeremia, Jesaja, Esegiël, Miga, Nahum en Maleagi die huwelik as metafoor gebruik om die verhouding tussen Jahwe en Israel uit te beeld. ${ }^{5}$ Sekere verskynsels wat in huwelike voorkom word oorgedra op die verhouding tussen God en sy mense om die aard van daardie verhouding uit te lig, negatief of positief. Die fokuspunt lê dus op God en sy verhouding en die metaforiese gebruik van huweliksbeelde vorm die referente om die

\footnotetext{
${ }^{4}$ Wat sou gebeur as van die ander gegewens ook letterlik as skeppingsordinansies gelees word, soos die sorg vir die diere (Gen 1:28) en om te leef van die plante wat saad gee (Gen $1: 29) ?$

${ }^{5}$ Vgl Botha, A se MA-verhandeling (2007) wat die huweliksmetafoor in Hosea 1 en 2 sien as die oorsprong van die Nuwe-Testamentiese metafoor "die kerk as bruid" in Efesiërs 5:21-33. Sy beskou Hosea 1 en 2 as interteks vir die Nuwe Testament dus as die locus classicus van die gebruik van Efesiërs 5:21-33 in huweliksbevestigingsformulier van die Nederduitsch Hervormde Kerk.
} 
verhouding met Hom uit te beeld. Dit is dan ook te verwagte dat aspekte wat die huwelik kenmerk, soos keuse van huweliksgenote deur families op eg Naby-Oosterse manier en ooreenkomssluiting, ook op die verhouding met God oorgedra sal word in die sin van uitverkiesing getrouheid, verbond.

Dit wil nie voorkom of die huwelik in die Bybel uitgesonder word as 'n selfstandige saak waaroor 'n geïsoleerde leerstuk opgestel kan word nie. Eerstens is dit 'n sosiale aangeleentheid wat nie in isolasie van ander gemeenskapsake staan nie. Daar is buitendien 'n verskeidenheid van vorms en beskouings oor die huwelik in die Ou Testament.

Tweedens is dit opvallend dat verwysings na die huwelik in die $\mathrm{Ou}$ Testament altyd binne 'n teologiese raamwerk gebruik word. In die teologisering van die Ou Testament word die huwelik saam met talle ander sake soos afkoms, land en volk gebruik. Dit kom altyd in 'n konstellasie van begrippe voor om veral die identiteit van die geloofsgemeenskap van Israel uit te spel as sosiale groep wat aan Jahwe behoort.

\section{HUWELIKSVERWYSING AS KOMPONENT VAN TEOLOGIESE KONSTRUKTE}

Omdat die bestaande huweliksformuliere nie die lading van die Ou Testament dek nie en neerkom op 'n letterlike Skrifgebruik, sal 'n ander weg ingeslaan moet word wanneer daar vanuit die Skrif oor die huwelik nagedink word. ${ }^{6}$ 'n Gebruik van Skrifgedeeltes los van hule primêre litere en sosio-historiese konteks beteken noodwendig 'n de-kontekstualisering van daardie Skrifgedeeltes. Selfs 'n bestekopname van wat die Skrif oor die huwelik "leer" (vgl Thatcher 1999:67) en 'n verwerking daarvan in "modelle" vir die huwelik, draai die sake agterstevoor. Die Bybel put uit die metaforiese skat van sosiale gegewens en maak daarvan in sy teologiese konstrukte gebruik. Die benadering in die formuliere maak van die gerefereerde verskynsels selfstandige konstrukte met teologiese pretensies. Die menslike huwelik is die metafoor en bepaalde eienskappe daarvan word teologiese oorgedra op die verbondsluiting tussen God en Israel om dit te konsepteer en nie andersom

\footnotetext{
${ }^{6}$ Die weg wat Thatcher (1999) volg is om vyf "Bybelse modelle" vir die huwelik te identifiseer (vgl Thatcher 1999:67-102). Dreyer-Kruger (2007) merk tereg op dat Thatcher die sosiale faktore losmaak van die wesenlike van sy modelle. Die benadering wat Thatcher moes volg was eerder om verskillende sosiale modelle vir die huwelik te identifiseer en te vra wat die Bybel metafories van daardie modelle maak in sy verkondiginsgestalte waar die fokus op God en die verhouding van mense met Hom en gevolglik met mekaar lê. Dreyer-Krüger is reg om die modelle wat Thatcher noem, dialekties interaktief met mekaar te lees, maar verkeerd om dit volgens die "oorkoepelende prinsiep" van die liefde te lees. Dit kom neer op 'n positivistiese verenging van die pluriforme Bybelse materiaal tot 'n Mitte.
} 
nie. ${ }^{7}$ Die verbond word in terme van die huweliksverbintenis verstaan en nie die huwelik in terme van die verbond nie. ${ }^{8}$ Die verbondsverhouding tussen God en sy volk word gekonsepteer vanuit die menslike ervaringswêreld van huwelikverbintenis, kontraksluiting en so meer.

Die voorstel wat hierdie artikel aanbied is dat verwysings na die huwelik saam met ander konsepte gebruik is as spreektaal om teologies oor die verhouding met God te reflekteer. Binne daardie konstellasie van begrippe wil die verwysing na die huwelik dus primêr dien om te sê wie God is. Omdat God egter nie anders geken kan word as in sy verhouding met mense binne hulle konteks van ervaring nie, sal die huwelikskonsep noodwendig saam met al die ander begrippe ook ter sprake kom om te sê wie die mense van God is. ${ }^{9}$ Die huweliksverwysing is binne hierdie konstellasie van begrippe dus ook 'n identiteitsmerker van Israel, 'n identifisering saam met ander begrippe van wat dit beteken om volk van God te wees. Die huwelik is nie 'n imperatief nie, maar 'n lewensverskynsel wat saam met ander begrippe gebruik word om oor God en mens te praat en uit te spel wat dit beteken as 'n mens in verhouding met God staan. Die huwelik word nie beveel nie, maar as lewensverskynsel saam met die res binne die konteks van die verhouding met God gestel. Dit lê eerder op die vlak van die etiek en konkretisering van die verhouding met God en wat dit impliseer. ${ }^{10}$ Die huwelikskonsepte wat gebruik is was nooit

\footnotetext{
${ }^{7}$ Murphy (1990:104) se opmerking na aanleiding van Hooglied is insiggewend: "The God of Israel transcended sex, but Israelite theology dared to use themes of human sexual love and marriage as metaphors in portraying the covenant relationship".

${ }^{8}$ Gilders (2007:4) wys daarop dat die huwelik as metafoor bepaalde beperkings het. In die boek Jubileë word die huwelik nooit as metafoor vir die verbondsverhouding met God gebruik nie. Die huwelik is kontraktueel en kan ontbind word. Dit kan dus nie die verhouding met God na behore beskryf nie. God het reeds by die skepping Jakob en sy nageslag uitgekies. Die verbond skep nie hierdie verbintenis tussen God en Israel nie. Dit bevestig dit net. Om hierdie God geïnisieerde onontbindbare verbintenis te beskryf, is die onverbreekbare band tussen vader en seun 'n meer getroue weergawe daarvan en word dit eerder as metafoor in Jubileë gebruik. Die normatiewe lê dus in die verhouding met God en nie in die huweliksverhouding nie. Aspekte van die huweliksverhouding kan daardie verhouding met God toelig, nie normeer nie. Die verhouding met God kan wel die huweliksverhouding normeer en eties deurgetrek word na die vorm en aard wat die huwelik in 'n bepaalde konteks behoort aan te neem.

${ }^{9}$ Die monoteïstiese beskouing van die Jahwisme sluit die mitologiese gedagte van 'n hieros gamos uit. God trou nie met ' $n$ godin nie en lewe op aarde is nie afhanklik van die verwekking daarvan deur hemelse gode nie. Die huwelik word ook nie gedeïfiseer nie, maar as deel van die res van God se skepping gesien. Dit het geen bo-aardse status nie en moet beleef en waardeer word as inherente deel van God se skepping. Soos enige ander fenomeen het dit die moontlikheid om metafories in die spreke oor God gebruik te word.

${ }^{10}$ Soos oor alle ander sake, word binne kulturele konteks eties gereflekteer oor seksuele moraliteit en getrouheid in die huwelik in plekke soos Deuteronomium 22:13-29. 'n Bepaalde waardestelsel ten opsigte van die huwelik word hier uitgewerk na aanleiding van wie God is en wat die verhouding met hierdie spesifieke God inhou in terme van die tyd en die omstandighede van die wat in Hom glo. Die huwelik is nie die maatstaf vir die verhouding met God nie, die verhouding met God is wel die maatstaf vir die huwelik en alle ander menslike verhoudings.
} 
aanduiding van 'n geïsoleerde bo-aardse, ewiglik onveranderlike saak nie. ${ }^{11}$ In veranderende omstandighede word telkens na ander vorms van die sosiale verskynsel van die huwelik verwys en dit word telkens in 'n herranskikking van hierdie en ander teologiese konstrukte gebruik.

As illustrasie van hierdie standpunt verwys ek eksemplaries na drie gedeeltes in die Ou Testament. Dit is die verhaal van die patriarge in Genesis 11:10-50:26 en die skuldgebede in Esra 9:6-15 en Nehemia 9:5b-37. In al drie gevalle kom die huwelik ter sprake binne 'n groter teologiese konstruk. Die konsep van die "land"12 kom in al drie konstrukte voor. Al drie gevalle dateer ook uit die tyd na die ballingskap, sodat ook die sosiale konteks van daardie tyd in berekening gebring moet word. In sosiaal-wetenskaplike navorsing word die geskiedenis van Israel gewoonlik in drie periodes verdeel: die patriargale, pre-eksiliese en Joodse periode. Volgens die oorvereenvoudigde ${ }^{13}$ beskouing van Malina (1981:105-116) kan een bepaalde huwelikstrategie aan elkeen van hierdie periodes afsonderlik gekoppel word. Die huwelikstrategie van die patriargale periode kan as versoenend beskryf word. In die periode wat die ballingskap voorafgaan was die strategie agressief. In die Joodse tydperk van die tweede tempel was die huwelik strategie verdedigend van aard. Die drie gedeeltes wat behandel word speel almal tydens die Tweede Tempeltyd, of sogenoemde Joodse periode af. Dit is volgens Malina se beskouing die verdedigende tydperk.

Hierdie gedeeltes verteenwoordigend natuurlik nie die hele $\mathrm{Ou}$ Testament nie. Hulle dien egter as illustrasie van die beredenering dat die huwelik as teologiese metafoor en as identiteitsmerker in die Ou Testament

\footnotetext{
${ }^{11}$ Murphy se siening van die boek Hooglied plaas die saak in die regte perspektief. Volgens Murphy (1990:100) is Hooglied "not designed to elaborate theological doctrine or to teach ethics, its unapologetic depiction of rapturous, reciprocal love between a man and a woman does model an important dimension of human existence, an aspect of life that ancient Israel understood to be divinely instituted and sanctioned".

${ }^{12}$ Wright (2004:19) gebruik in sy publikasie oor Ou-Testamentiese etiek die konstruk van God, Israel en die Land as "the three pillars of Israel's worldview, the primary factors of their theology and ethics". In sy hoofstuk "Culture and family" (Wright 2004:327-362) gebruik hy weereens hierdie driehoek en stel die uitgebreide gesin met die grond wat hulle besit (vgl Wright 2004:339-340) as die kern waarom hierdie driehoek gebou is. Onder uitgebreide gesin verstaan hy dan vanselfsprekend die saak van die huwelik. Wright (2004:328) se uitgangspunt in hierdie hoofstuk is dat "Israel built theology and ethics around the particular cultural manifestation of family that was at the heart of their own society ...". Buiten die problematiek wat Wright se werk oplewer ten opsigte van die verhouding teologie en etiek, is twee sake vir my belangrik. My opinie dat die vraagstuk van die huwelik primêr 'n etiese vraagstuk is, word hier bevestig. Tweedens is dit uit Wright se werk duidelik dat besinning oor huwelik en gesin vanuit 'n konstellasie van begrippe, soos land-Israel-God, onderneem moet word. Dit is iets wat ek hier vanuit 'n teologiese begripskonstruk probeer aantoon. ${ }^{13}$ Soos onder aangetoon sal word is geen periode slegs beperk tot een tipe huwelikstrategie
nie.
} 
voorkom. Hierdie benadering kan ook op ander gedeeltes uit die Bybel toegepas word.

Alhoewel die Genesisboek na die partriagale tydperk verwys, kom dit in sy finale en huidige vorm uit die tweede tempel periode, in besonder die Persies-Agaemeniede tydperk (538-333 vC). Dit verteenwoordig sienings wat in daardie tyd in omloop was. Die werk van die Kronis verwys na die tyd tydens en na die tempel herbou is in $516 \mathrm{vC}$. Die standpunte wat in daardie tydperk ingeneem word oor veral ongewensde huwelike moet eweneens teen die agtergrond van die sosiale wêreld van daardie tyd gelees word. Alhoewel die gedeeltes wat as voorbeelde gebruik word uit een tydperk van die geskiedensi kom, is dit duidelik uit die literatuur dat daar selfs nie eens in daardie een tyd ' $n$ eenvormige beskouing van die huwelik bestaan het wat as norm vir die huwelik uit die Bybel aangewys kan word nie.

Die werkwyse wat gevolg word is om die scenario wat die gedeeltes aanbied te verstaan vanuit die literêre struktuur van die materiaal en dan van daar terug te werk na die sosiale agtergrond van die aanbieding. Die literatuur skep met woordbeelde 'n wêreld waarin die oortuigings van die skrywer/s uitgebeeld word. Daar is egter baie gapings in die literatuur wat die huidige leser moet probeer opvul deur onder andere 'n sosiaal-wetenskaplike konstruksie te skep van die agtergrond waaruit daardie literatuur kom.

\section{DIE GENESISSIKLUSSE}

Die Genesisverhale is volgens Steinberg (1993:143) in die tyd na die ballingskap finaal afgerond. Die manier waarop die geskiedenis van die patriarge hier aangebied word, was binne die sosio-historiese konteks van daardie tyd die literêre tegniek wat gebruik is om die identiteit van die groep te bepaal. Hulle is dus anachronisties gebruik om die ou tradisies so te intepreteer dat dit die eietydse sosiale omstandighede kon legitimeer. Alhoewel die verhale oor die patriargale tyd gaan, is hulle daarop gerig om vanuit daardie materiaal vir die eie tyd sanksionering vir die eie groepsidentiteit te gee. Hulle bied op metaforiese vlak die ideologie aan van 'n denkrigting in die na-ballingskaptyd oor wie werklik tot die volk van Israel behoort en wie nie.

Soos in Esra-Nehemia was daar konflik tussen die mense wat agtergebly het en die wat uit die ballingskap teruggekeer het. Hierdie verhale probeer uitmaak dat die mense wat teruggekeer het die eintlike volk van God is. Die oervaders word daarom ook geïdealiseer as mense wat van die land van hulle voorsate vervreem was. Dieselfde gebeur in die Kronistiese materiaal. Steinberg (1993:146) is daarom van mening dat hier ' $n$ strategie aan die werk is "to legitimate the group in exile and, when they return to allow 
them to exert control over those who remained on the land; those in the exile are the true descendants of the Terahite lineage now seen in its horizontal genealogical formation".

'n Verdere komponent in hierdie materiaal is dus die van genelaogie. In 'n tydperk waarin 'n defensiewe ingesteldheid (vgl Malina 1981:105-116) die botoon gevoer het, word genealogieë ingespan om die identiteit van die Judese groep te bepaal. In die ou Naby-Oosterse wêreld het die familiale instelling een van die hoekpilare van die sosiale struktuur ${ }^{14}$ gevorm. Identiteit uitgespel in terme genealogie is dus ten nouste verbind aan die huwelik en die gesin. Die verhale omlyn die omvang van die gemeenskap in terme van familieverwantskap (genealogieë). ${ }^{15}$ Die verhale oor afkoms word dus gebruik om die vraag te antwoord wie die werklike Israel is. Hierdie verhale waarin genealogieë gebruik word om familieverwanskap aan te toon “... are used as metaphors ${ }^{16}$ for understanding the sociopolitical relationship in the postexilic community." (Steinberg 1993:147).

Almal wat die verhale hoor en hulle kon vereenselwig met Tera, Abraham se pa, en bloedverwantskap met hom kon aantoon, is as deel van Israel beskou (vgl Steinberg 1993:143). Veral in die tyd van die ballingskap toe Israel sonder 'n land was, het dit belangrik geword om deur middel van genealogieë te kon aantoon dat iemand deel was van die "ware Israel". Dit is dan ook Steinberg $(1993: 147)$ se tese dat hierdie vertellings bedoel was "... to shape reality in favor of those removed from the land, rather than to reflect conditions on their return".

Steinberg het die materiaal in Genesis vanuit sowel 'n literêre hoek as die hoek van antropologiese teorie oor bloedverwantskap bestudeer. Sy rekonstrueer eers die sosiale wêreld wat in die teks self aangebied word sonder om die sosio-historiese konteks waarin die vertelwêreld geskep in ag te neem. Sy probeer dan om hierdie gerekonstrueerde vertelwêreld te verstaan in die lig van die resultate uit die sosiale wetenskap, veral die van kruis-kulturele navorsing oor bloedverwantskap en die modelle wat daar ontwikkel is.

Die boek Genesis word gewoonlik verdeel in die Oergeskiedenis (Gen 1-11) en die Geskiedenis van die Oervaders (Gen 12-50). Steinberg (1993:39)

\footnotetext{
${ }^{14}$ Kyk Van Eck (2007:83-98) vir 'n uiteensetting van die sosiale strukture van die Medittereense wêreld.

${ }^{15}$ Deist (2000:249) wys daarop dat genealogiëe in die Bybel nie bedoel is om historiese dokumente te wees nie maar eerder die sosiale funksie vervul van "items ascribing meaning to social and political relations and functionally legitimizing privileged social position".

${ }^{16}$ Deist (2000:252) ondersteun hierdie standpunt wanneer hy aandui dat narratiewe in die Hebreeuse Bybel "employ genealogy as a metaphor to express social relations among groups in the Palestinian region".
} 
sien egter Genesis 11:27 as inleiding tot die tweede deel van die boek. ${ }^{17}$ Die nageslag van Sem in Genesis 11:10-26 word vanaf 11:27 afgespits op die familie van Tera. Die res van die Genesisboek gaan oor die nageslag van Tera. Volgens Steinberg (1993:135) is alles wat volg saamgestel rondom die konstellasie van die drie begrippe "heirship, marriage and ownership of land".

Steinberg verdeel Genesis 11:27-50:26 in drie siklusse: Genesis 11:1025:11, Genesis 25:12-35:29 en Genesis 36:1-50:26. ${ }^{18}$ Daar word elke keer dieselfde tipe plot gebruik. Elke siklus begin met 'n inleidingsgedeelte waarin die formule gebruik word: "Hier volg die vertelling oor $X$ se nageslag." (Gen 11:10-26; 25:12-18; 36:1-43). In elke siklus kom die vraagstuk van nageslag na vore. Die voortgang van die geslagslyn van Tera word nie net deur stamhuwelike bepaal wat die erfgrond binne die kring van bloedverwante moet hou nie, maar ook deur die tipe huwelike wat gesluit word. Verskillende omstandighede vertraag telkens die oplossing van die probleem van waar'n opvolgende geslag vandaan sal kom. Sodra die probleem egter opgelos is en daar nageslag is, beweeg die vertelling na die volgende siklus. In hierdie probleemoplossing is erfgename, huweliksluiting en land telkens sentrale temas.

Die land het te doen met erflating. In die eerste twee siklusse ontvang die persoon wat as die eintlike erfgenaam na vore kom nie net die familienaam nie maar ook die familiegrond. Daar is 'n sterk ooreenkoms tussen erfreg en bewoning van die land wat ge-erf is. In die eerste SaraHagar siklus vereis Abraham dit van Isak om in die land te bly as hy 'n afstammeling van die oervader Tera wil wees. Jakob word in die tweede siklus eers as Isak se erfgenaam erken nadat hy van Paddan-Aram af terugkom het na sy geboortegrond toe. In die derde Lea-Ragel siklus word erfgenaamskap en land van mekaar geskei. Jakob se kinders trek (tydelik) weg uit die land en verwantskap aan een van die kinders van Jakob word nou die voorwaarde vir bloedverwantskap aan Tera in die plek van bewoning van

\footnotetext{
${ }^{17} \mathrm{Vgl} \mathrm{Brueggemann}(1982: 105,114)$ vir 'n soortgelyke "alternatiewe" indeling van die boek. Brueggemann begin die tweede deel van Genesis reeds by Genesis 11:30-12:9. As eindresultaat van ' $n$ ingewikkelde ontwikkeling in die tradisies bestaan die gedeelte vir Brueggemann (1982; 106-107) uit Sara-materiaal. Lot-materiaal, Isak-materiaal en die genealogie van Abraham.

${ }^{18}$ Die meer tradisionele indeling verdeel die tweede gedeelte in Genesis in vier "manlike" siklusse: die Abrahamsiklus (Gen 12-24), die Isaksiklus (Gen 25-27), die Jakobsiklus (Gen 28-36) en die Josefsiklus (Gen 37-50). Speiser (1990:viii-ix) verdeel dit in die verhaal van Abraham (Gen 12-25:18), die verhaal van Jakob (Gen 25:19-37:2a) en Josef en sy broers (Gen 37:2b-50:26). Wenham (1987) verdeel dit volgens die "toledot"-opskrifte in die Familiegeskiedenis van Tera (Gen 11:27-25:11), Familiegeskiedenis van Ismael (Gen 25:1218), Familiegeskiedenis van Isak (25:19-35:29), Familiegeskiedenis van Esau (36:1-37:1) en Familiegeskiedenis van Jakob (37:2-50:26). Dit is hieruit duidelik dat daar geen eenstemmigheid bestaan oor die indeling van Genesis nie.
} 
die land wat ge-erf is. Die tema van die land fluktueer dus tussen die drie silusse van bewoning na vervreemding.

Die tema van afkoms word bepaal deur die huwelik van die ouers. In hierdie verhale word 'n huwelik as legitiem beskou as daar nageslag daaruit gebore kan word. Die keuse van 'n huweliksmaat bepaal dan of 'n afstammeling ingesluit sal word in die geslagslyn van Israel of nie. Gesien vanuit die kulturele perspektief van bloedverwantskap ("cross-cultural kinship studies", vgl Steinberg 1993:116), is die verwekking van 'n nageslag afhanklik van die keuse van 'n huweliksmaat en die status van die kinders wat daaruit gebore word, veral wanneer dit by erflating kom. Huwelike word gesluit om die be-erwing van die land ${ }^{19}$ binne die grense van bepaalde bloedverwante ${ }^{20}$ te hou. Die oudste kind is gewoonlik die primêre aanspraakmaker op die erflating. Indien daar meer as een vrou is, ontstaan daar 'n hiërargie in die status van hulle kinders wat op sy beurt bepalend is vir die stamboom van die familie en die orde van erflating. Ook hier is daar dus fluktuasie in die bepaling van die geslagsdraer.

In die drie siklusse is daar sprake van drie verskillende soorte huwelike. Omdat dit die status is van die vrou wat telkens die rangorde van erflating bepaal, noem Steinberg elke siklus volgens die vrouens wat daarin ter sprake is. Genesis 11:10-25:11 is in haar navorsing die Sara-Hagar Siklus waarin dit gaan oor 'n huweliksreëling waarin 'n man 'n tweede vrou van laere status as sy tweede vrou neem ("polycoity" - vgl Steinberg 1993:152). Genesis 25:12-35:29 vorm die Rebekka Siklus waarin dit gaan oor 'n monogame huwelik. Genesis 36:1-50:26 vorm die Lea-Ragel Siklus waarin 'n man met meer as een vrou trou, in hierdie geval met susters, wat gelyke status in die huwelik geniet ("sororal polygyny" - vgl Steinberg 1993:152). Hierdie benamings van die siklusse volgens die stammoeder ${ }^{21}$ is nie so onvanpas as die opmerking van Deist (2000:245) in ag geneem word dat die pa die belangrike figuur is wanneer dit by identietit en status kom nie, maar "a person's mother is the real distinguishing factor in a household". Omdat die genealogie volgens die naam van die man bepaal word, is dit beter om te

\footnotetext{
${ }^{19}$ Die "land" is 'n baie belangrike tema in die Ou Testament. Vir 'n behandeling van hierdie tema kyk Davies (1974:15-35), "The land in the hexateuch"; Davies (1974:36-48), "The Land in the prophets".
${ }^{20}$ Volgens Brueggemann word gedeeltes soos Genesis 12:1-3 en 22:15-18 aan mekaar verbind deur die Leitmotif van die belofte van die land. Maar "within the frame of the land promise, the promise of an heir takes on increasing importance" (Brueggemann 1982:109). Van hier af is dit 'n logiese stap om 'n derde been by te voeg wanneer Steinberg die klem laat val op die bepalende rol van die ma van die erfgenaam.
${ }^{21}$ Deist (2000:264) tref ' $n$ belangrike onderskeid tussen die beperkte juridiese reg wat ' $n$ vrou het en die hoë sosiale status wat sy geniet.


verwys na die Abraham-Sara-Hagar Siklus (Gen 11:10-25:11), die IsakRebekka Siklus (Gen 25:12-35:29) en die Jakob-Lea-Ragel Siklus (Gen 36:150:26).

In die Abraham-Sara-Hagar Siklus (Gen 12:1-25:11) gaan dit oor Abraham en Sara. Omdat Sara nie kinders het nie word die probleem van nageslag ' $n$ baie akute probleem vir Abraham. Hy probeer eers deur die aanneming van sy nefie Lot en toe van sy bediende Eliëser 'n nageslag verseker. Dit is egter nie die korrekte prosedure nie. Hy neem vervolgens Hagar as tweede vrou en begeef hom dus in 'n poligame ${ }^{22}$ huwelik wat in verwantskap-navorsing bekend staan as "polycoity" (vgl Steinberg 1993:152). Wanneer Abraham uiteindelik by al twee vroue kinders het, is die probleem egter nog nie opgelos nie. Die krisis wat nou opduik is wie sy eerste erfgenaam ${ }^{23}$ sal wees wat erfregtelik aanspraak op sy eiendom het. Soos in die geval van Tera se ander seuns, Nahor en Haran, verdwyn die belang van Hagar se seun Ismael op die agtergrond en die hooffokus val nou op die jonger Isak as die hooffiguur in Abraham se nageslag. Hierin is die status van sy ma deurslaggewend. ${ }^{24}$ Die afloop van gebeure in hierdie siklus is dus opgebou rondom die tipe huweliksluiting wat Abraham aangaan met twee vrouens en die rol wat dit gespeel het om 'n nageslag te verseker.

In die Isak-Rebekka Siklus (Gen 25:12-35:29) verskuif die klem na die erfgename. Isak gaan met Rebekka 'n monogame huwelik aan. 'n Tweeling word uit die huwelik gebore en die vraag is wie van Jakob of Esau dan nou die eintlike erfgenaam sal wees van Isak wat die bloedlyn voortsit. Vertellings volg waarin die konflik in die gesin uitgebeeld word waar Isak kant kies vir Esau wat eerste gebore is en Rebekka weer vir Jakob wat tweede gebore is. Deur tegnieke van manupilasie word die saak oënskynlik wederregtelik in Jakob se guns besleg. Die probleem oor die opvolger van Isak is opgelos en die verhaal kan nou aanskuif na 'n volgende fase. Die geslagslyn is vasgeteel en die nalatenskap is bepaal.

In die derde Jakob-Lea-Ragel Siklus (Gen 36:1-50:26) word die temas van bloedlyn en erflating nie op dieselfde manier uitgewerk as in die vorige twee siklusse nie. Genealogie word nie hier direk verbind aan die huwelike

\footnotetext{
${ }^{22}$ Deist (2000:247) wys daarop dat poligamiese huwelike gesluit word waar die ekologiese faktore ' $n$ prominent manlike rol vereis in die voortsetting van die geslag. Die man word dus die belangrikste figuur in hierdie tipe huwelik.

${ }^{23}$ In agragriese gemeenskappe het die "oudste" seun aanspraak gemaak op dubbel die erflating wat sy broers ontvang. Hier merk Deist (2000:265) op: "First-born was however, not necessarily a chronological position, but a status conferred on any son of the father's choice".

${ }^{24}$ Deist (2000:248) toon aan dat dit moontlik is in "a male genealogy, especially when polygamy is involved, a person may be more clearly identified with reference to the relevant mother". Voorbeelde hiervan kom voor in 1 Kon 11:26; 14:31; 15:2; 22:42.
} 
wat gesluit word nie. Die erflating van die land staan ook nie direk in verband met die besluite oor wie die erfgename moet wees nie. Die tema van erfgename wat nie dadelik gebore word nie, kom ook nie hier voor nie. Jakob trou met twee susters en hulle slavinne Bilha en Silpa. Hierdie poligame tipe huwelik word in die navorsing "sororal polygyny" (vgl Steinberg 1993:152) genoem. Die susters het gelyke status en gevolglik het Jakob se twaalf seuns en een dogter gelyke erfregtelike status. Die lyn van erfreg word nie meer volgens oudste en eerste aanspraakmaker bepaal nie, maar almal is gelyke erfgename. Die lyn van erfreg word hier dus parallel gesegmenteer. Die verhaal van die Bybel verander nou vanaf 'n monolitiese bloedverwantskap na 'n parallelle verwantskap van twaalf stamme wat saam die volk van Israel uitmaak. Die Siklus verduidelik hoe bloedverwantskap en erfreg hanteer word in die geval waar daar huwelike van "sororal polygyny" (vgl Steinberg 1993:116) aangegaan is.

Dit is "cross-cultural kinship studies" (vgl Steinberg 1993:116) wat ons help om die strekking van hierdie siklus beter te verstaan. Die verandering in die reëls van die spel oor erfgename is te wyte aan die verandering in die aard van die sosiale strukture. Steinberg (1993:132) verklaar daarom ook: "The pattern may shift as long as there is flexibility in social organization and in the decision-making process on social organization. Kinship decisions reflect the demands of those who participate in them". Waar die erfgename in die vorige siklus in die land moes bly wat hulle ge-erf het, verlaat die seuns in hierdie siklus die erfgrond en gaan bly hulle in Egipte.

Die genealogie word in hierdie geval nie net deur die aard van die huwelik bepaal nie, maar ook deur die verbinding van geslagslyn en verblyf in die land. Waar 'n erfgenaam in die land wat hy erf moes bly om te kwalifiseer as erfgenaam in die vorige siklusse word dit hier losgemaak van die land en verduidelik hoe die nageslag van Jakob buite die land kan bly waar Abraham en Isak gebly het en nog steeds die nageslag van Tera kon wees. Hulle wat buite die land te lande gekom het is net soveel deel van die geslagslyn as hulle wat binne die land gebly het.

Wat dus in Steinberg se studie oor Genesis 11:10-50:26 na vore kom, is dat die model wat aan die na-ballingse gemeenskap aangebied word om rigting te gee aan hulle identiteit van 'n veranderlike konstruk van genealogiehuwelik-land gebruik maak. Binne die driehoek van hierdie begrippe word die terrein van Israel se identiteit uitgespel. Die interrelasie van hierdie drie begrippe is nie gefikseer nie, maar gekoppel aan die veranderlikheid van elkeen van hierdie begrippe. Drie verskillende vorms van huwelike word aangedui wat elke keer op 'n ander manier bepaal hoe die genealogiese lyn sal ontwikkel en die land geërf sal word. Die genealogiese lyn word weer bepaal deur die beste soort huwelik om 'n nageslag te verseker wat die land 
kan erf. In twee gevalle speel die land die belangrikste rol in die bepaling van wie aan die geslagslyn behoort al dan nie. In die derde geval word die land heeltemal buite rekening gelaat.

Huwelik saam met genealogie en land word dus hier die identiteitsmerker vir die na-ballingse geloofsgemeenskap. Die inhoud en betekenis van die huwelik word nie net elke keer verander volgens die verhouding met die twee ander begrippe land en nageslag nie, maar neem ook telkens ander vorms aan om te kan bydra tot die vestiging van die unieke identiteit van Israel. Dit is nie die vorm of kultuurpatroon wat hier bepalend is nie - dit is elke keer veranderlik - maar die funksie van die huwelik binne 'n konstellasie van begrippe om die geloofsidentiteit van Israel te bepaal. Ons kan geen "Bybelse huweliksmodel" uit hierdie veranderlike konstruksies aandui nie.

\section{DIE KRONISTIESE BOETEGEBEDE UIT DIE PERSIESE TYD}

Gedurende die tyd dat Juda 'n provinsie van die Persiese Ryk was (538-333 $\mathrm{vC}$ ), was sy inwoners verplig om 'n eie unieke identiteit te ontwikkel. Nuwe omstandighede het nuwe uitdagings gestel. Daar is gepoog om te besin oor wat dit beteken om 'n Judeër in daardie tyd te wees. Dit is gedoen in aansluiting by die voor-eksiliese monargale tyd van Israel en Juda. Die Mosaïese wetstradisies is herinterpreteer op 'n skaal wat selfs die Deuteronomistiese hervormings van net voor die ballingskap oortref het (vgl Bossman 1979:32). ${ }^{25}$

In die Kronistiese werk Esra-Nehemia ${ }^{26}$ word Esra uitgebeeld as 'n gesant van die Persiese Ryk wat na Juda terugkeer om godsdienstige hervorming rondom die Mosaïese wette, die kultus en ondertrouing deur te voer. Die hervormings wat die goewerneur Nehemia teweeg gebring het, het Judese identiteit bepaal in terme van etniese ekslusiwiteit, ondersteuning van die Jerusalemse tempel, kultiese reinheid, konformering aan die Tora en die verbod op bepaalde huwelike. In beide gevalle funksioneer die huwelik as identiteitsmerker. Dit word telkens binne 'n groter konstellasie van teologiese konsepte gebruik.

\footnotetext{
${ }^{25}$ Bossman (1979:32) verwys na hierdie herinterpretasie as 'n midrasj metode wat die eksegetiese en hermeneutiese tegnieke voorsien het vir die daaropvolgende ontwikkelings en toepassings van die Bybelse legalistiese tradisies in nuwe uitdagende omstandighede soos wat Judaïsme stelselmatig 'n metode ontwikkel het om ou norms op nuwe situasies toe te pas.

${ }^{26}$ In die debat rondom Esra en Nehemia skaar ek my by die groep wat Esra-Nehemia as een deurlopende narratief sien. Vgl Williamson (1999:276) wat die verdeling in twee boeke as die werk van latere vertalers beskou. Ek reken ook dat dit van 'n Kronistiese skool kom. Uit hierdie selfde groep kom ook 1 en 2 Kronieke op 'n ietwat later tyd.
} 


\subsection{Die Boetegebed in Esra 9:6-15}

Die gebed in Esra 9 is saamgestel volgens die genre van die boetegebed (penitential prayer) met sy tipiese elemente van lofprysing, smeking, belydenis van sonde en onderwerpe soos verbond, land en wet (vgl Venter 2005:545546). Dit neem tegelyk ook die vorm aan van 'n preek ("sermon"; vgl Van Grol 1999:210-211) ${ }^{27}$. Die begrip "land" speel die sentrale rol in die gebed. Dit gaan oor die bewoning van die land sedert die vaders tot by die tyd van die gebed. Die bewoning van die land is teologies verbind aan die saak van die wet van God. Die wet is onder andere teen ondertrouing met die ander inwoners van die land. As "verkeerde" huwelike aangegaan word bring dit noodwendig afgodery mee wat op sy beurt lei tot verbeuring van die land ( $\mathrm{vgl}$ Deut 7:1-4).

Die simmetriese struktuur van die gedig plaas ondertrouing met inwoners van die land in die sentrale fokuspunt in Esra 9:10-12. "Huwelik" en "land" word hier met mekaar verbind. Rondom hierdie kernpunt staan die omraming van 9:8-9 en 9:13-14 waarin die effek van die tipe huwelik wat die Israeliete aangaan direk betrek word daarop of hulle in die land mag woon of nie. In die buitenste omraming van die gedig in 9:6-7 en 9:15 gaan dit oor Israel se skuld wat hulle voor God moet bely omdat hulle die wet oortree het en gaan ondertrou het. Verkeerde huwelike staan dus binne die omraming van verbeurde aanspraak op bewoning van die land, wat weer binne die groter omraming staan van die skuld van Israel voor God. ${ }^{28}$

Die beklemtoning van die gedig dat Israel alle aansprake verbeur het, maar nogtans toegelaat word om weer te kon terugkeer na die land, is 'n strategie van die gedig om oor God te teologiseer in terme van huwelik, land en skuld. ${ }^{29}$ Die volgehoue oortreding van Israel deur sy verkeerde huweliksluitings en gevolglike verbeuring van die land, wys juis op die goedheid en geduld van God. Hy is die groot God van geregtigheid wat sy ongelyke vennote teen alle logika in liefhet sonder om enige teenprestasie van hulle te verwag. So word skuldbelydenis hier in wese die keerkant van geloofsbelydenis in God.

Hierdie belydenis druk ' $n$ bepaalde stempel op die geloofsgemeenskap af. Dit bepaal hulle identiteit in terme van hulle geloof in God. Esra se gebed vertoon opsigtelik homiletiese kenmerke. Dit staan ook binne die raamwerk

\footnotetext{
${ }^{27}$ Volgens Van Grol (1999:210) maak die drie retoriese vrae in Esra 9:10-14 meer sin uit as deel van 'n preek as van 'n gebed. Sy standpunt ondersteun my gedagte dat ons hier met 'n vorm van teologisering te doen het.

${ }^{28}$ Vir 'n vollediger uiteensetting kyk Venter (2005:549-552).

${ }^{29}$ Bossman (1979:36) praat van "four principal value concepts" nl Israel, Tora, God se geregtigheid en God se genade, wat al vier hier in Esra 9 "interact in a harmonious relationship, forming the warp and woof of Ezra's midrashic rhetoric". Bossman (1979:37) verwys daarna as "intertwining the principal value concepts of tradition".
} 
van kultiese handelings. Esra se treuraksies in Esra 9:3-5 en 10:1a is volgens die tipiese godsdienstige rourites wanneer hy sy klere skeur, sy hare en baard uittrek en vas (9:4). Hy begin met die boetegebed wanneer dit tyd is vir die aandoffer (9:4-5). Hy doen ook sy gebed by die tempel (10:1). Hy gee onmiddellik daaraan 'n kultiese konnotasie.

Hierdie verbinding tussen skuldgebed en kultus staan teen die agtergrond van die uitbeelding van Esra in Esra 7:1-10:44. ${ }^{30}$ Teen die tyd dat hy in Jerusalem aankom, is die tempel reeds herbou en in gebruik geneem. Esra se taak is om nou ook die huishouding van God te herbou. In sy heropbou van die godsdiensgemeenskap en sy kultiese diens, hoor Esra dat daar sommige is wat met nie-Judese vrouens getrou het (Esra 9:1-2). In terme van sy ideologie dat die identiteit van die geloofsgemeenskap bepaal word deur hulle toegewydheid ${ }^{31}$ aan God, word hierdie huwelike ${ }^{32}$ vir hom 'n toetssaak. Volgens sy priesterlike ideologie is toegewydheid aan God iets wat nie net die priesters en Leviete raak nie, maar die hele gemeenskap. Waar die voorskrifte van die wet gewoonlik net die huwelike van die priesters bepaal het, word dit nou vir hom iets wat ook betrekking het op die hele godsdiensgemeenskap. So word huwelike wat volgens Esra se maatstawwe nie voldoen aan die vereistes van God se Wet nie, een van die kernprobleme in die herstel van die geloofsgemeenskap. Huwelik, land, tempel, huishouding van God en belydenis word almal deel van een konstellasie van begrippe wat die herstelde identiteit van die geloofsgemeenskap bepaal. ${ }^{33}$

\footnotetext{
${ }^{30}$ Brown (2005a) sien veral in die eerstepersoons vertelling waar Esra self outobiografies aan die woord kom (Esra 7:27-9:15) die teologiese kern van die boek Esra. Volgens Brown (2005:330) is die oorkoepelende perspektief waaruit die verhaal vertel word, dat die Here oor alle aardse koninkryke regeer en dat die Wet die sleutel is om Hom te ken. Hierdie oorhoofse tema staan op die drie temas van die soewereiniteit van God, God se goedheid en die onderhouding van die Wet. Alhoewel Brown se artikel verhelderend is oor die verteltegnieke wat in Esra voorkom, lyk dit nie of sy standpunt oor die teologie van die boek werklik verteenwoordigend is van die vertelling nie.

${ }^{31}$ Brown (2005b:457-458) gebruik die begrip "heiligheid" vir hierdie toewyding aan God. Hierdie toewyding is volgens Brown (2005b:458) belangriker "than even the closest of human relationships: marriage". Kollektiewe heiligheid is selfs belangriker as individuele verantwoordelikheid.

${ }^{32}$ Zlotnick-Sivan (2000:9) verwys na die herhaling van die verbod op ongewenste huwelike uit die Pentateug (Eks 34:15-16 en Deut 7:34) as die opsigtelike kenmerk van die gebed. Waar die Pentateugdele op die gevaar van afgodsdiens en godsdiensvervreemding wys, is die oorwegings hier eerder van ekonomiese aard - dieselfde oorwegings wat die Dinaverhaal in Genesis 34 ten basis lê waar Gamor ter wille van handelsbetrekkinge 'n huwelik tussen Dina en Sigem probeer beklink.

${ }^{33}$ Bossman (1979) werk nie met immanente terme uit die eenheid nie, maar tipiese waardes in midrasj literatuur. Die vervlegting van waardes soos Israel, Tora en God, lei volgens hom noodwendig by Esra tot godsdienshervorming wat direk inspeel op huweliksvoorskrifte. Die rasionaal vir die huwelikshervormings by Esra transendeer volgens hom die verbod op vreemde huwelike in Deuteronomium.
} 
Esra se identifisering van bepaalde ongewensde huwelike as belemmering van sy heropbou program berus op sosiale identifisering van groepe in die samelewing van sy tyd. Hy het die idealbeeld in sy kop van hoe die herstelde geloofsgemeenskap moet leef en wie hulle moet wees. Die eiening van bepaalde soort huwelike word dus ' $n$ strategie om skeidslyne ${ }^{34}$ deur die gemeenskap te trek en beheer uit te oefen oor groepsvorming. Teenoor hierdie binnegroep skans hy 'n buitegroep af met wie assosiasie, hier in terme van huweliksluiting, bedreigend vir die groepsidentiteit is. Hy eien homself dus ' $n$ "prophetic tradition of moral authority" (Zlotnick-Sivan 2000:10) toe. Hierdie bedreigende buitegroep is nie-Joodse vrouens wat op een lyn gestel word met die vroeëre Kanaäniete, Hetiete, Feresiete, ens (vgl Deut 7:14), volkere wat teen die tyd van Esra nie meer bestaan het nie. Dit is egter duidelik dat Esra se definisie van wie 'n Jood is en wie nie, bepaal word deur sy tempelteologie en sy heropbou program. Dit is nie noodwendig dat hy hier met etniese kategorisering werk nie. ${ }^{35}$ Dit kan ander bevolkingslae of selfs ander Judeërs wees wat nie dieselfde godsdiens oortuigings of kultiese tempelideale as hy deel nie.

\subsection{Die Boetegebed in Nehemia 9:5b-37}

Ook hierdie gebed ${ }^{36}$ is 'n belydenis ${ }^{37}$ van God se getrouheid en sy liefde (Neh 9:22) in terme van Israel se skuld. Die historiese retrospeksie in Neh 9:5b-31

\footnotetext{
${ }^{34}$ Zlotnick-Sivan gaan van die standpunt uit dat die teruggekeerde Judeërs hier afgeskans word van die plaaslike bevolking wat agtergebly het. Die wat agtergebly het, is nie net uitgesluit van die herbou van die tempel (Esra 4:1-5), deelname aan die rituele en feeste (Esra 6:19-22) en die groep nie, maar soos in Eseg 44 ook van heilige ruimte. Ruimte word ook deur Esra herdefinieer. Heilige ruimte, heilige feeste en deur die huweliksmaatreël nou ook huisgesinne 'become foci of bonding as the boundaries between 'us' and 'them' are drawn" (Zlotnick-Sivan 2000:11).

${ }^{35}$ Zlotnick-Sivan (2000:11) se slotsom dat Esra hier "uses his superior moral position to reinforce an agenda of genealogy and to propose a new ideology of what it means to be a Jew" oorspeel die inligting van die verhaal wat 'n "gap" hier los en nie invul van watter vrouens gepraat word nie.

${ }^{36}$ Williamson (1999:286-287) onderskei tussen die "belief system" van die redaktor van die boek Nehemia en die karakter Nehemia in die boek. Die gebed in Nehemia 9 is uit pas met die res van Esra-Nehemia en is eerder die oortuigings van die redaktor van die boek. Die gebruik van die historiese oorsig in die gebed druk die redaktor se oortuiging uit dat die huidige omstandighede die voortsetting is van die sosiale, politieke en religieuse omstandighede wat sedert die Babiloniese ballingskap ontstaan het. Ballingskap en herstel is nie die oorwegende temas hier nie, maar eerder die stem van die bevolking wat in die land agtergebly het. Vir die redaktor wat die gebed hier ingesluit het tussen wetlesing (Neh 8) en verbondsvernuwing (Neh 10), "the community's identity was forged not just by past history but also by the continuity of habitation in the land" (Williamson 1999:287).

${ }^{37}$ Oeming (2006:574) beskryf die gebed as a "creed", 'n geloofsbelydenis van die naballingse gemeenskap. Die primêre bedoeling van die teks is om die geaardheid van God en die aard van die ware Israel uit te spel.
} 
volgens die tradisionele skema sonde-straf-bekering-vergewing, ${ }^{38}$ spel die oortredings van Israel deur die loop van die geskiedenis uit in terme van die gebooie van God en die land wat God aan hulle gegee het. Verse 33-35 spiëlbeeld die skuldbelydenis van $5 b-31$ deur in dieselfde terme die skuld van die huidige geslag te bely. Die klaaglieddeel in verse 36-37 neem die tema van die land op en skets die ironiese omstandighede dat die Judeërs slawe is in hulle eie land. ${ }^{39}$

In die boek Nehemia vind daar drie byeenkomste plaas (7:73b-8:12, 8:13-18; 9:1-10:39). Die gebed in 9:5b-37 word tydens die derde byeenkoms (9:1-10:39) gebid. Die patroon by elke byeenkoms is presies dieselfde. 'n Verwysing na die bepaalde tyd waarop die byeenkoms plaasvind, word gevolg deur'n verwysing na die wet wat gelees word en die reaksie van die vergadering daarop. Die reaksies loop uit op 'n formele program van herstel in terme van die wet wat aan die geloofsgemeenskap voorgehou is. Hierdie program word uitgespel in Neh 11:1-13:31. Die godsdiensgemeenskap van Jerusalem beloof skriftelik om aan ses dinge aandag te gee. Hulle sal ondertrouing met "heidense vroue van die land" stopsit (10:30; 13:23-31), die sabbatdag onderhou (10:31; 13:15-22), die sabbatsjaar eerbiedig (10:31), tempelbelasting betaal (10:32-33), hout vir die brandoffers in die tempel voorsien (10:34), en bydraes vir die tempel gee (10:35-39; 12:44-47).

Die gebed verteenwoordig dus hier 'n hervormingsprogram waarin die etos van die gemeenskap in terme van die wet van God hersien word. Binne die raamwerk van tyd en omstandighede word besin oor die aard ${ }^{40}$ van die Judese geloofsgemeenskap, sy teologie en die betekenis van sy ryk en geskakeerde tradisie. Die skuldbelydenis van die gebed verhoog die dissonans tussen die bestaande waardestelsel en motiveer die omvorming van die gemeenskap in terme van die omstandighede van hulle tyd. In hierdie soeke na 'n nuwe identiteit ${ }^{41}$ identifiseer die gemeenskap struikelblokke wat die program in die weg staan. Een daarvan is huwelike wat buite die parameters van die groepsidentiteit val. Die projek vereis gevolglik drastiese

\footnotetext{
${ }^{38}$ Van Grol (1999:209) merk op dat Esra 9, Nehemia 9 en 2 Kronieke 12 van hierdie skema afwyk omdat die vergewing nie volledige verlossing beteken nie. Dit is getemper deurdat die Judeërs nog steeds onder die oorheersing van die Perse staan. God het hulle nie totaal verwoes nie, maar tydelike uitkoms in hulle eie land gegee om weer die tempel te herbou.

${ }^{39}$ Vir 'n vollediger bespreking kyk Venter 1995:722-723.

${ }^{40}$ Kvanvig (2007:8) noem Neh 8-10 'n "Master Narrative" waarin die verhaal vertel word van die hergeboorte en nuwe identiteit van die Judeërs. ' $n$ Ware Judeër is iemand wat gevorm is deur die geskiedenis van die berit en die torah.

${ }^{41}$ Manfred Oehming (2006:582) noem die Esra-Nehemia komposisie "an imposing attempt to create a model of a 'true Israel' during the mid-Persian Period (ca 450 BCE)".
} 
maatreëls soos die in Neh 9:23-31 om die religieus-kulturele transformasie te voltrek.

Alhoewel die skuldgebede van sowel Esra as Nehemia met die konstellasie van konsepte land en wet werk en die saak van ongewensde huwelike ${ }^{42}$ by albei voorkom, is daar tog opsigtelike verskille ${ }^{43}$ in hulle teologiese ontwerpe. ${ }^{44}$ Esra se tempelgerigde priesterlike teologie knoop die identiteit van die gemeenskap besonder sterk aan huwelike. Dit is die groot struikelblok wat hy identifiseer in die realisering van 'n nuwe kultiese gemeenskap. By Nehemia is daar ook sprake van die land, wet en huwelike. Hier word die saak van die regte huwelike egter binne 'n veel groter projek ${ }^{45}$ geplaas waarin dit gaan oor godsdienssuiwerheid, feeste en infrastruktuur vir die tempeldiens. Die invulling van die betekenis van huwelike word by albei in terme van die basiese begripsapparatuur van Deut 7:1-4 gedoen, maar die naunses daarvan word by elkeen binne 'n ander teologiese konstruk uitgewerk.

Dit is opvallend dat die saak van ongewensde huwelike as identiteitsmerker ook in ander literatuur uit dieselfde tyd en kort daarna voorkom. Vir wat die historiese korrektheid daarvan ookal is, beweer Josefus in sy Oudhede XI, 306-312 dat Manasse, die broer van die hoëpriester Jaddua, Jerusalem verlaat het uit reaksie op Nehemia se hantering van die "gemengde huwelike" en 'n tempel op die berg Gerisim in Samaria teen die einde van die vyfde eeu gebou het. Dit het die identiteit van die Samaritane

\footnotetext{
${ }^{42}$ Zlotnick-Sivan praat van die "vreemde Ander". Volgens Zlotnick-Zivan (2000:3) gaan dit in Esra-Nehemia oor die drie ineengestrengelde temas: "the 'reading' of a sacred text, public spectacles, and the vilification of the foreign 'other'". In hierdie konstruksie is land dus gelyk aan openbare byeenkoms.

${ }^{43}$ Williamson (1999:279) kontrasteer Nehemia se simplistiese verwysing na Salomo se huwelike in Neh 13:26 met die "exegetically far more elaborated approach of Ezra in Ezra 9:12". Waar Esra 'n hele paar wetstekste kombineer om sy drastiese beleid van ontbinding van die huwelike te substansieer, verwys Nehemia slegs na een van daardie tekste (Deut 7:3) sonder om dieselfde hoë vlak van wetsargumentering aan die dag te lê as Esra. Nehemia beroep hom op leke vlak op die geskiedenis van die volk om die huidige situasie te hanteer, terwyl Esra verfynde eksegese gebruik.

${ }^{44}$ Van Grol (1999) vergelyk die gebede/preke in Esra 9 en Nehemia 9 aan die hand van die begrip "servitude". In Esra 9 gaan dit om 'n poging om die geloofsgemeenskap daarvan te weerhou om opnuut weer te oortree. God het aan hulle nou vir 'n tydjie genade betoon, maar dit staan onder bedreiging indien hulle weer oortree. Die toon is hier positief. In Nehemia 9 is die toon negatief. Die ou sondige gedrag en gevolglike onderworpenheid gaan maar steeds voort. Die enigste manier om daarvan weg te breek is om die geskrewe ooreenkoms aan te gaan wat in Nehemia 10 geskets word.

${ }^{45}$ Willamson (1999:282) sien Nehemia as 'n politikus vir wie die instellings van die godsdiens in diens staan van die groter nasionale belang. Sy "belief system" is pragmaties en ongekompliseerd. "His overriding concern is for a strong Jewish identity within an accepted imperial framework" (Williamson 1999:282). Tempel, kultiese personeel en godsdiens praktyke is parefernalia wat "points of cohesion and focus" (Williamson 1999:282) aanbied.
} 
bepaal. In die Boek van die Wagte (1 Henog 1-36), die boek Jubileë en die boek van Aramese Levi, al drie uit die derde-tweede eeu vC, gaan dit ook oor ongewensde "gemengde huwelike", spesifiek tussen priesters en nie-Joodse vrouens. Ook hier het dit oor die debat van identiteit gegaan en wat dit bevorder of belemmer. Ook hier is die debat bepaal deur eietydse omstandighede en bepaling vanuit groepidentiteit oor dit wat identiteit bepaal.

\subsection{Sosiaal-wetenskaplike profilering van ongewendse huwelike by Esra en Nehemia}

'n Gattung is altyd verbind aan 'n Sitz im Leben. Die genre "skuldgebed" ("penitential prayer") wat in Esra 9 en Nehemia 9 voorkom, reflekteer een of ander lewensituasie. ${ }^{46}$ Becking (2003:260) eien die situasie as die van "a political ritual to bind the community to a specific moral rule". Volgens hom kom gebede soos hierdie gewoonlik voor in 'n situasie van 'n persoon of 'n gemeenskap wat vrede met sy verlede wil maak sodat hy/hulle 'n nuwe begin kan maak. Die literêre eiening van 'n literatuur tipe lei dus noodwendig na 'n rekonstruksie ${ }^{47}$ van die lewensituasie waarin dit normaalweg gebruik word. Dit bring ons by sosiaal-wetenskaplike navorsing en die verskillende moontlike scenarios wat daardeur gekonstrueer ${ }^{48}$ kan word. Hierin is dit belangrik om te onthou dat die soeke na 'n eie identiteit ${ }^{49}$ in die vroeg-Tweede Tempeltyd baie prominent gefigureer het en baie dikwels aan voorskrifte vir huweliksluiting verbind is.

Gedurende die tyd van die ballingskap het daar ' $n$ verandering in die sosiale struktuur van Israel gekom. Die voormalige stam- en familie-eenhede is vervang met wat beskryf kan word as die "bet 'abot"-eenhede (vgl McNutt 1999:199). Dit was 'n redelike groot groepering wat die tradisionele kleiner familie-eenhede ingesluit het, maar ook individue wat hulle met die bepaalde groep vereenselwig het en met hulle geïdentifiseer het. Waar die vorige

\footnotetext{
${ }^{46}$ Williamson (1999:276 verwys na die "pitfalls in seeking to move direct from text to history". Daar is 'n verskil tussen die "belief system" van die gemeenskap na wie 'n literêre werk verwys en die ideologie wat in die teks self aangebied word.

${ }^{47}$ Becking (2003:261-263) wys daarop dat Sitz im Leben 'n problematiese begrip is. Beïnvloed deur die negentiende eeuse positivisme is van Gunkel tot Koch die Sitz as rekonstrueerbare geskiedenis gesien. In die postpositivistiese kritiek, waarin die vraag gevra word of dit ooit moontlik is om 'n "geskiedenis van oud-Israel" te skryf, word geskiedenis as 'n narratief op die verlede gesien. Becking (2003:263) sien daarom Sitz im Leben as 'n "hypothesis on the past".

${ }^{48}$ Vir die modelle van Philip R Davies, Lester L Grabbe en ander eksponente van hierdie benadering, kyk Brown (2005b:442 voetnote 13 en 14).

${ }^{49} \mathrm{Vgl} \mathrm{hier} \mathrm{die} \mathrm{titel} \mathrm{van} \mathrm{die} \mathrm{artikel} \mathrm{van} \mathrm{Jon} \mathrm{L} \mathrm{Berquist} \mathrm{(2006),} \mathrm{"Constructions} \mathrm{of} \mathrm{Identity} \mathrm{in}$ Postcolonial Yehud". Zlotnick-Sivan (2000:3) meen dat Esra-Nehemia "appears to be fundamentally concerned with issues of identity and boundaries".
} 
eenhede bepaal was deur bloedverwantskap, verander die maatstawwe nou en word dit onder andere gebaseer op kriteria soos mense wat in die ballingskap op dieselfde plek gebly het.

In die soek na eie identiteit en bepalings van die grense van die groep, het ekonomiese, politieke, sosiale en religieuse faktore 'n integrale rol gespeel (vgl McNutt 1999:206). ${ }^{50}$ Berquist (2006:57-58) ${ }^{51}$ wys daarop dat godsdiens nie die enigste faktor was wat identiteit bepaal het nie. Soms was dit glad nie 'n faktor nie. ${ }^{52}$ As groepspersone met diadiese persoonlikhede (vgl Van Eck 2007:83) was dit belangrik om die identiteit van die groep waaraan jy behoort te ken. Dit was ' $n$ hele proses van identiteitsvorming waarin talle faktore 'n rol gespeel het. ${ }^{53}$ In die konflik wat daar met ander groepe en ander definisies van groepsidentiteit ontstaan, speel die saak van huweliksluiting en die verbod op die sluit van bepaalde huwelike 'n belangrike rol. Binne 'n eerskaamte kultuur is dit 'n "social control mechanism" (Deist 2000:293) wat met groot doeltreffendheid gebruik kan word om die buitegroep met skande te identifiseer en die eie groep met eer in verband te bring. As "sensitiwiteit vir openbare reputasie" (Van Eck 2007:86) kon skaamte dus as 'n uiters effektiewe tegniek uitgebuit word om groepe te ostraseer en die belange van die eie groep te bevorder. Om die identiteit van die groep uit te bou kan op 'n strategie van assosiasie en disassosiasie besluit word wat bepaalde huwelike as eervol beskou omdat dit die groepsidentiteit versterk, terwyl ander as bedreigend gesien kan word en deur die assosiasie met skande ontmoedig kan word. Omdat skaamte ook as vroulik gesien kan word (vgl Van Eck 2007:88) kon skaamte ook maklik aan bepaalde vroue as ongewensde huweliksmaats toegeskryf word. Alhoewel daar variasies in die sosiaal-

\footnotetext{
${ }^{50}$ Brown (2005b:450) is skepties oor 'n sosio-ekonomiese analise. Hy erken dat sulke faktore wel 'n rol kon speel, maar meen dat Esra se beswaar "entirely spiritual in nature" was. Volgens Brown (2005b:449) is dit nie ondertrouing met vreemdelinge as sulks wat die probleem is nie, eerder ondertrouing met vreemdelinge wat sinkretisme en afgodsdiens beoefen het.

${ }^{51}$ Berquist (2006:64) sê dat insig in Judese identiteitsvorming in die Persiese tyd 'n komplekse analise is van "multiple social levels with attention to numerous processes in which people internalize the forces of imperialization and decolonization".

${ }^{52}$ Berquist (2006:57-58) wys daarop dat daar sedert die ontdekkings by Elefantine en Kuntillet 'Ajrud nie meer simplisties gedink kan word dat alle Judeërs dieselfde godsdiens gedeel het nie. Die gedagte wat vir geruime tyd gehuldig is in navorsingskringe dat daar 'n verskuiwing van nasionale na religieuse identiteit in die Persiese tyd was, gaan nie meer op in die lig van die gedifferensieerdheid van die Judese gemeenskap nie. In Haggai, Sagaria, Esra en Nehemia is daar 'n politieke sowel as 'n religieuse leier aanwesig. Dit is nie meer moontlik om Judese identiteit slegs in geografiese of politieke of religieuse terme uit te druk nie. Eksterne sowel as interne keuses het groot skakerings in groepsidentiteit moontlik gemaak.

${ }^{53}$ Berquist (2006:63) praat van "identity formation". Hy sien identiteit nie in terme van statiese kategorieë nie maar as uiters vloeibare prosesse waarop verskillende kragte inwerk en individue en gemeenskappe tot verskillende rolvervullings lei.
} 
wetenskaplike navorsing na groepsvorming voorkom, kan hierdie tipe dissipline help om die die uitbeelding van die huwelik in Esra-Nehemia beter te verstaan.

Die omstandighede wat in Esra sowel as Nehemia uitgebeeld word, is die van interne konflikte en spanninge in die Persiese provinsie Juda. ${ }^{54}$ Die botsing was tussen mense wat van die ballingskap af teruggekeer het en die wat daar bly woon het. Daar was ook konflik tussen die stedelike bevolking en die plattelandse gemeenskap en ook tussen die Judese gemeenskap en die noordelike Samaritane. Die stryd om die bepaling en handhawing van sosiale grense het op sy duidelikste uitgekom in die gedwonge ontbindings van huwelike wat in Esra 9-10 en Nehemia 13 uitgebeeld word.

Omdat die werklike demografiese samestelling in Juda in hierdie tyd nie duidelik is nie en daar nie uitgespel is wat met "vreemde vroue" bedoel word nie, is ons hier grootliks van teorievorming afhanklik. ${ }^{55}$ Volgens Eskanazi en Judd (vgl McNutt 1999:202) kon hierdie vrouens enigiets wees van vrouens wat nie deel was van die ballingskap groep nie, of aan 'n ander bevolkingsgroep behoort het, of selfs aan Judese groepe behoort het wat godsdienstige praktyke beoefen het en oortuigings gehuldig het wat radikaal van die van die teruggekeerde ballinge verskil het.

'n Ander moontlikheid is dat eiendomsreg en familieverwantskap so eng verwant was dat bepaalde ongewensde huwelike daadwerklike sosioekonomiese gevaar vir die gemeenskap ingehou het. Deur bepaalde huwelike kon hulle van hulle erfgrond vervreem raak en uiteindelik hulle identiteit verloor. Berquist (vgl McNutt 1999:204) wys uit dat dit in sowel Esra as Nehemia gaan oor die ekonomiese as politieke konsekwensies van hierdie huwelike.

\footnotetext{
54 John W Wright (2006:67-89) redeneer aan die hand van 'n analise van 1 Kron 2:3-4:23 en 8:1-40 dat die identiteit van die Judeërs nie deur die grense van die Persiese provinsie Jehud bepaal is nie, maar eerder deur verwantskap en beskermheerskap. Die bewoningskonsentrasies suid van Jerusalem vanaf Betlehem tot by Hebron en in die noorde en weste van Jerusalem na die kant van die Sjefela toe het geografiese grense oorskry en groepsidentiteit geskep - wat natuurlik ook bepalend was vir huweliksluitings.

${ }^{55}$ Brown (2005b:439-445) onderskei drie kategorieë in die teorieë oor wie die "inwoners van die land" en die "vreemde vroue" was: 1. Dit was heidense nie-Jode uit die nasies rondom Juda (met wie Esra in 'n tweede eksodus gekonfronteer word soos wat Josua met sewe heidennasies gekonfronteer is). 2. Dit was Judeërs wat nie uit die ballingskap teruggekom het nie maar in die land agtergebly het (en dus in religieus-politieke konflik met die groep van Esra was). 3. Dit was 'n konglomerasie van Judeërs (wat nie deel was van die ballingskap) en van omringende volkere wat deur Esra vereenselwig was met die volkere wat Israel tydens die intog in Kanaän uit die land moes uitdryf. Veral onder die tweede kategorie wys Brown op teorieë wat op sosiaalwetenskaplike metodes gegrond is.
} 
Esra fokus op die problematiek van leierskap ${ }^{56}$ en sien in ongewenste huwelike ' $n$ bedreiging vir die vereistes wat aan leiers gestel word. Nehemia het vrouens uit die tradisionele vyande van Israel (Asdod, Ammon, Moab) in die oog en is bevrees dat die kinders uit daardie huwelike nie meer Hebreeus sal kan praat nie en kultuurvervreemding teweeg sal bring.

Volgens Berquist het dit nie oor etniese suiwerheid ${ }^{57}$ gegaan nie, maar eerder oor streek kompetisie en ekonomiese differensiasie binne die provinsie Juda. Binne 'n konteks van harde mededinging op ekonomiese en magsgebied tussen ekonomiese streke sou die verbod op gemengde huwelike kon bydra tot ' $n$ gevoel van Joodse solidariteit in eie geledere. In 'n situasie waarin politieke beheer en ekonomiese selfstandigheid onder 'n elite groep in die Jerusalemse gemeenskap uiters belangrik was, kon Esra se maatreëls eerder wys op huwelike wat met vrouens binne die eie klassegroep gesluit moet word. Huwelike buite hierdie verband sou ekonomiese en politieke gevolge hê wat die leiersgroep sou bedreig. Binne sowel die sisteemas konflik-teorië waarin groepe gesien word as mededingers vir skaars bronne soos ekonomiese goedere, prestige en mag, is die afbakening en identiteit van die groep van uiterste belang. Huwelike kan hierdie grense oorskry en 'n ontwrigtende faktor begin word.

Dit vereis op sy beurt weer navorsing na hoe strukture en sosiale norms volgens groepsidentiteit gevorm word, wat die uitwerking van afwykings van hierdie norme is en die patrone wat sulke afwykings aanneem, veral in die geval waar grense van die groep bepaal word deur godsdiens, geslag en klas. Esra 9-10 moet dan bestudeer word as die uitwerking van 'n Judese immigrante gemeenskap wat in 'n proses gewikkel is om by nuwe situasies aan te pas en uitgelewer is aan 'n netwerk van veranderlikhede wat so 'n groep in transito stuur en lei. Soos wat hierdie nuwe grense en identiteit vorm begin aanneem het, kon vrouens wat aanvanklik aanvaarbaar was as huweliksgenote, mettergaan in die proses van herdefinisie as "outsiders" gesien word.

Nog een ander moontlikheid is dat die Judeërs wat teruggekeer het hulleself teenoor die wat in die land agtergebly het as sosiaal en ekonomies benadeelde minderheidsgroep kon begin sien. Die ongewensde huwelike kan dan gesien word as huwelike wat aangegaan is met die bedoeling om aan die

\footnotetext{
${ }^{56}$ Berquist (2006:58-59) wys op die bydrae wat rollespel in sosiaal-wetenskaplike navorsing kan speel om gemeenskapsidenteit in terme van leiersfigure te bepaal. Hy wys egter op die gevaar wat dit inhou om rolle in die gemeenskap as onveranderlik te sien.

${ }^{57}$ Berquist (2006:54-56) wys daarop dat die bepaling van identiteit in terme van etnisiteit bemoeilik word deur twee faktore. Etnisiteit as rasgebaseerde denke is ' $n$ hedendaagse begrip wat vreemd is aan die pre-moderne denke rondom verwantskap. Tweedens is die Judees-Persiese tekste altyd "unclear, inconsistent, and always contested" (Berquist 2006:55) oor identiteit. Om die huwelik in die Persiese tyd aan etnisiteit te verbind is dus riskant.
} 
ondergeskikte groep te ontsnap deur met vrouens uit die Judeërs wat agtergebly het te trou en so aanvaarbare status by die meerderheid te kry.

\subsection{Opsomming}

Esra sowel as Nehemia gebruik die huwelik binne 'n konstellasie van terme om in hulle hervorminsgprogramme die geloofsgemeenskap in die rigting van 'n bepaalde identiteit te stuur. Esra verbind wet, land en huwelik om ' $n$ tempel gefokusde gemeenskap te vorm wat uitvoering gee aan God se wet ook in die huwelike wat hulle aangaan. Nehemia verbind wet en land aanmekaar en stuur in die rigting van 'n geloofsgemeenskap wat skriftelik onderneem om aan God toegewy te wees. Hy fokus op die areas van godsdienssuiwerheid, feeste en die tempeldiens. Onder die probleme wat hierdie voorneme dwarsboom identifiseer hy onder andere sekere soort huwelike.

Esra sowel as Nehemia betrek die huwelik binne 'n teologiese konstellasie van land en wet. Albei betrek die huwelik direk op die geloofsidentiteit van die geloofsgemeenskap. Die huwelik kry dus hier 'n geloofskonnotasie wat bo die alledaagse uitreik. Nie een van die twee gee egter nader besonderhede oor die soort huwelike waarin hulle bedreigings vir die hervormde identiteit sien nie. Dit maak sosiaal-wetenskaplike ondersoek nodig. Uit daardie benadering word dit duidelik dat dit hier gaan om die dinamika van groepsvorming in die gemeenskap en al die faktore wat daarin ' $n$ rol speel. Die huwelik is dus hier ' $n$ integrale deel van die gestaltegewing van die geloofsgemeenskap aan hulle geloofsidentiteit.

\section{SLOTSOM}

Dit is uit die drie siklusse van Genesis en die skuldbelydenisse van Esra en Nehemia duidelik dat die huwelik ' $n$ identiteitsmerker is wat in 'n konstellasie van begrippe funksioneer om die aard van die geloofsgemeenskap te bepaal. Dit is nie 'n konstante gegewene wat onveranderd op sy eie funksioneer nie. Die huwelik kan nie geïsoleer word van die sosiale konteks van die tyd waarin dit voorkom nie. Die vorm en die betekenis daarvan word telkens bepaal deur die funksie wat dit het binne die groter struktuur van die identiteit van die geloofsgemeenskap in die konkrete omstandighede van die tyd.

Die huwelik is geen absolute wat op sy eie staan en wat groter is as die res van sosiale verskynsels wat die aard van die belewenisse van die geloofsgemeenskap bepaal nie. Net so min as wat reëls oor groepsvorming, grensbepaling, identiteitsformulering, ekonomiese maatreëls vir oorlewing, of magbeoefening uit hierdie gegewens afgelei kan word, kan bindende huweliksreëls uit hierdie gegewens geabstraheer word. Soos die dinkraamwerk van die Bybel die parameters verskaf waartussen die 
geloofsgemeenskap sy geloof konkretiseer volgens sy gegewe omstandighede, so bied dit die riglyne vir sy besinning oor hoe die huwelik gestalte kan gee aan sy unieke identiteit van mense wat met hulle hele lewe aan God behoort.

\section{Literatuurverwysings}

Becking, B 2003. Nehemiah 9 and the problematic concept of context (Sitz im Leben), in Sweeney, M \& Ben Zvi, E (eds), The changing face of form criticism for the twenty-first century, 253-265. Grand Rapids, MI: Eerdmans.

Berquist, $J \mathrm{~L}$ 2006. Constructions of identity in postcolonial Yehud, in Lipschits, $O$ \& Oeming, M (eds), Judah and the Judeans in the Persian Period, 53-66, Winona Lake, IN: Eisenbrauns.

Bossman, D 1979. Ezra's marriage reform: Israel redefined. BTB 9, 32-38.

Botha, A 2007. Die demistifikasie van die metafoor "die Kerk as Bruid" vanuit 'n narratief-pastorale perspektief. Ongepubliseerde MTh-verhandeling, Universiteit van Pretoria (elektroniese weergawe).

Brown, P A 2005a. Point of view in the book of Ezra. Bibliotheca Sacra, 162, 310330.

Brown, P A 2005b. The problem of mixed marriages in Ezra 9-10. Bibliotheca Sacra, 162, 437-458.

Davies, W D 1974. The Gospel and the land: Early Christianity and Jewish territorial doctrine. Berkeley, CA: University of California Press.

Deist, F E 2000. The material culture of the Bible: An introduction. Sheffield: Sheffield Academic Press.

Dreyer-Krüger, A E 2007. 'n Bybels-hermeneutiese perspektief op die huwelik. MThverhandeling, Universiteit van Pretoria. (elektroniese weergawe).

Gilders, W K 2007. The concept of covenant in Jubilees. Konsepartikel voorberei vir die Vierde Henogseminaar te Camaldoli, Italië, 08-12 Julie 2007.

Kvanvig, H S 2007. Enochic Judaism - a Judaism without the Torah and the Temple? Konsepartikel voorberei vir die Vierde Henogseminaar te Camaldoli, Italië, 08-12 Julie 2007.

Malina, B J 1981. The New Testament world: Insights from cultural anthropology. Louisville, KY: John Knox.

McNutt, P 1999. Reconstructing the society of ancient Israel. London: SPCK.

Murphy, R E 1990. The Song of Songs: A Commentary on the Book of Canticles or the Song of Songs. Minneapolis, MN: Fortress. (Hermeneia - A Critical and Historical Commentary on the Bible.)

Nederduitsch Hervormde Kerk van Afrika. Diensboek: Formulier vir die Bevestiging van die Huwelik (1), (2) \& (3). http:Iwww.nhk.co.za/HOOF.htm/Diensboek.

Oeming, M 2006. See, we are serving today (Neh 9:36): Nehemiah 9 as a theological interpretation of the Persian period, in Lipschits, $O$ \& Oeming, M (eds). Judah and the Judeans in the Persian Period, 571-588, Winona Lake, IN:

Eisenbrauns.

Speiser, E A 1990. Genesis: The Anchor Bible: Introduction, translation and notes. New York: Doubleday.

Steinberg, N 1993. Kinship and marriage in Genesis: A Household economics perspective. Minneapolis, MN: Fortress. 
Thatcher, A 1999. Marriage after modernity: Christian marriage in postmodern times. New York: New York University Press.

Van Grol, H 1999. Indeed, servants we are: Ezra 9, Nehemiah 9 and 2 Chronicles 12 compared, in Becking, B \& Korple, M C A (eds), The crisis of Israelite religion: Transformation of religious tradition in exilic and post-exilic times, 209-227. Leiden: Brill.

Van Eck, E 2007. Die huwelik in die eerste-eeuse Medittereense wêreld (I): Vroue in die mans se wêreld. HTS 63(1), 81-128.

Venter, P M 1995. Die aard van die geloofsgemeenskap in Nehemia 9, HTS 51, 720731.

Venter, P M 2005. Die skuldgebed in Esra 9:6-15. HTS 61, 545-563.

Williamson, H G M 1999. The belief system of the Book of Nehemiah, in Becking, B \& Korple, M C A (eds), The crisis of Israelite religion: Transformation of religious tradition in exilic and post-exilic times, 276-287. Leiden: Brill.

Wenham, G J 1987. Genesis 1-15. Waco, TX: Word (elektroniese weergawe).

Wright, C J H 2004. Old Testament ethics for the people of God. Downers Grove, IL: InterVarsity.

Wright, J W 2006. Remapping Yehud: The borders of Yehud and the genealogies of Chronicles, in Lipschits, $\mathrm{O}$ \& Oeming, M (eds), Judah and the Judeans in the Persian period, 67-89, Winona Lake, IN: Eisenbrauns.

Zlotnick-Sivan, H 2000. The silent women of Yehud, in Journal of Jewish studies 51(1), 3-18. 